\title{
FOREIGN DIRECT INVESTMENT FROM THE INDUSTRY ZONE ALPKA AND ITS IMPACT ON THE REGION LABOUR MARKET
}

DOPAD PY̌ ÍMÝCH ZAHRANILL NÍCH INVESTIC Z PRŠ MYSLOVÉ ZÓNY ALPKA NA REGIONÁLNí TRH PRÁCE OKRESU LOUNY

\section{ING. SYLVIE KOTÍKOVÁ}

\author{
Katedra ekonomie $\mid$ Department of Economics \\ Ekonomická fakulta Faculty of Economics \\ Technická univerzita $v$ Liberci Technical University of Liberec \\ $\bowtie$ Studentská 1492/2, 41617 Liberec, Czech Republic \\ E-mail: sylvie.kotikova@tul.cz
}

\section{Annotation}

This paper aims to analyze and evaluate the impact of selected foreign direct investment in the Louny District, based on the data from annual reports of multinational companies situated in the industrial zone Alpka. This region contends with high unemployment and the absence of strategic employer. The basic research question is whether and to what extent can foreign direct investment help to solve of regional problems in the labour market in this structural afflicted region. Based on the comparative analysis of information from companies' annual reports and statistics from the Czech Statistical Office and the CzechInvest association, the research results presented in the paper point at the fact, to what extent foreign direct investment from one industrial zone could reduce the unemployment rate in this particular district. The research results illustrate and quantify the contribution of these investments from the start of the industrial zones until 2013. The contribution of these investments to address the regional problem of high unemployment rates is illustrated by hypothetical unemployment rate, in other words what would be the situation on the regional labour market in the case of the absence of these investments in the industrial zone. Based on the comparative analysis of data from the period 2000 - 2013 foreign direct investment from the industrial zone could reduce regional unemployment rate by 1.7 p.p. per year on average.
\end{abstract}

Key words

foreign direct investment, labour market, regional development, unemployment rate

\section{Anotace}

Tento $p$ Śsp 円jek má za cíl zhodnotit vliv vybraných $p$ Śmých zahrani| ních investic na okres Louny, a to prostŚsednictvím údaj丁 $z$ výroḷ ních zpráv nadnárodních firem lokalizovaných v prTmyslové zón円

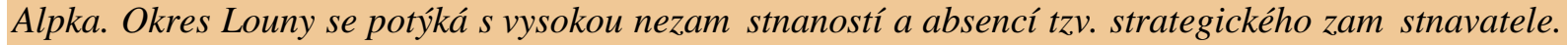
Základní výzkumnou otázkou je, zda a pŚsevợ́m pak do jaké míry dokáğ́ pŚ́mé zahranil ní investice napomáhat $k$ Śgéní regionálních problém丁 na trhu práce v tomto strukturáln Đpostiógeném regionu. Na základ komparativní analýzy informací z výroḷ ních zpráv firem a údaj丁 L LUU a CzechInvestu je kvantifikován dopad pŚmých zahrani! ních investic z konkrétní prTmyslové zóny na nezam \:nanost $v$ okresu. PŚ́nos tḩhto investic $k$ Śégení regionálního problému vysoké míry nezam Пtnanosti je ilustrován na hypotetické mí́se nezam \.tnanosti, resp. jaký by byl stav na regionálním trhu práce

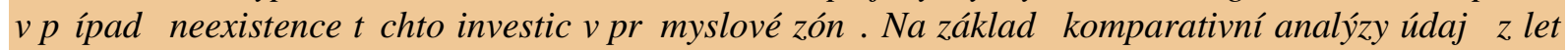
2000 ï 2013 pŚmé zahrani! ní investice z prTmyslové zóny dokázaly snígit regionální nezam \:tnanost

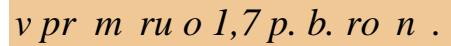

\section{Klílová slova}

míra nezam ク̧:tnanosti, pŚmé zahrani! ní investice, regionální rozvoj, trh práce 
JEL classification: F21, J60, J64, R11, O47

\section{Introduction}

Foreign direct investment (FDI) is a term which is commonly used within a global measuring scale. Currently, it is already very substantial part of the Czech economy. In times of economic crisis, it significantly supported the Czech economy when FDI employed more staff and created greater added value than before the crisis despite the general slump of manufacturing (Ġmanová, 2013).

FDI in the Czech Republic have both supporters and opponents in the context of investment incentives. The first group consider them as a powerful engine of economic growth, the know-how representative, new technologies and strategic employer. Foreign investment, or rather investments of multinational corporations, help to solve the economic problems of the host region, particularly the unemployment, e.g. FDI is involved in the unemployment almost up to $6 \%$ in the most structurally disadvantaged regions of Ústí nad Labem and Moravskoslezský (Ġmanová, 2013).

The opponents point at the arrival of low-quality producers which are remarkable for mass production with low added value that only take advantage of investment incentives (including support for the creation of new working places) and do not create any lasting linkages in regions and an outflow of FDI is very likely. Many of them may have a negative impact on technological convergence of regions, on the other hand there is an increase of the inertia risk; i.e. the closure of the region in the trap of technologically undemanding productions which are in high demand of labour in the intensive industries and thus they permanently damage their competitiveness (Ġmanová, Treg், 2011).

Despite many criticism of FDI, states and regions compete how to get them as they create comprehensive systems of investment incentives, offer the full range of the industrial zones and make attractive localities for potential investors. Although there are negative aspects, FDI bring primarily new working places, new technologies, knowledge and expertise to the region. These elements might have positive impact on regional competitiveness (Pavlínek, 2004).

As a consequence of foreign direct investment introduction there is a general increase in living standards, effective demand and additional creation of GDP. FDI also contributes to the increasing labour productivity in the regions. These impacts are mutually linked and closely related to the situation on the labour market which are affected by FDI.

Although this topic has become a very topical issue namely in the case of regions with the highest capital inflows, there are no studies that quantify this impact in more details yet - at the level of concrete industrial zones and companies. This is the purpose of this article.

\section{Aim and methodology}

The aim of this paper is to evaluate impact of the specific FDI and its impact on the regional labour market of the Louny district, which is directly affected by the FDI, based on the analyse of the FDI. Particular consequences of FDI, which have effect on the regional labour market, are shown and analysed at the actual specific examples of foreign investors from the industrial zone Alpka are analysed in this paper.

The statistics of the Czech Statistical office and the data of the CzechInvest are used as the main primary sources utilized for the creation of this article.

The main method used for evaluating the impact of the below mentioned FDI is a comparative analysis. Data of the regional labour market drawn from the state institutions, primarily from the CSO, are compared to the information obtained from the annual reports of analyzed FDI. The impact of 
analyzed FDI on the regional labour market is quantified by differences between the real rate of unemployment:

$$
=-* 100(1)
$$

and so-called the hypothetical unemployment rate :

$$
=\stackrel{+}{+} * 100
$$

where U represents the real number of unemployed persons according to the CSO's data, L represents labour and E stands for the sum of the number of employees of analyzed FDI in each years.

A difficulty of this methodology resides in the fact that companies often take on workers from other regions and foreigners. Unfortunately, such information is difficult to find out. Nevertheless, according to the CSO's data in the Ústí region, there is particularly low number of foreigners on the labour market in the district Louny compared to other districts within the Ústí region. It makes only $6.6 \%$ in total (CSO, 2013).

Given of the above mentioned, this low employment of foreigners should not be emerged significantly in a hypothetical calculation of the employment rate.

\section{Foreign direct investment and unemployment in the district}

Long-term high unemployment can be considered as a fundamental socio-economic problem of the region. This region is characterized by one of the highest unemployment rate within the Czech Republic ï 10,7\% in 2013 making it one of the ten districts with the highest unemployment rate in the Czech Republic (MPSV, 2014).

High unemployment rate is not the only one serious issue of this regional labour market. Characteristic The long-term imbalance is distinctive: on one hand there is the existence of job vacancies and on the other hand we speak of the existence of potential workers, who are unskilled for these positions. There is a discrepancy between supply and demand in the labour market, i.e. discrepancy between a focus of schools (or rather a supply of capacities of educational branches) and the focus of the regional economy. This fact is supported by the statistics of the labour market. According to the Labour Market Statistical Yearbook 2012, a proportion of job vacancies to unemployed applicants is in the highest category $(25 \%)$ by people with higher specialized education, followed by the number of apprenticeship graduates $(17,28 \%)$ and persons with university degree $(8,67 \%)$. It is obvious that despite the excess of labour supply over demand there is a large number of job vacancies due to inappropriate qualifications and other reasons (MPSV, 2013).

Since 1998 investment incentives are provided in the Czech Republic primarily structurally affected regions of type Louny district. Based on data of CzechInvest to December 31, 2013 was the situation of FDI at 506 407,07 million CZK in the Czech Republic. 78 340,89 millions CZK (about 15.5\%) was invested in the Ústí nad Labem region. Roughly one-fifth of FDI in the Ústí nad Labem region is located in the Louny district (CZK 17,987.89 miles), particularly in the industry zone Alpka (IZ Alpka) 2851.64 miles CZK where 4 investors situated their investment. Three Italian and one from Germany. Currently 7 companies are in the IZ Alpka (March 2014). Four of them are FDI, which are so called greenfields and were attract through investment incentives to the region. Given this statistics, it is possible to say, that this district and especially the IZ Alpka is connected with the concentration of FDI. This fact has effect and influence of regional labour market There are 4 branches of multinational corporations located in the industry zone Alpka now (see the Tab. 1), (CzechInvest, 2014). 
Tab. 1: Firms operating in the industry zone Alpka in 2014

\begin{tabular}{|c|c|c|c|c|}
\hline $\begin{array}{c}\text { Name of company } \\
\text { (Investor) }\end{array}$ & $\begin{array}{c}\text { Size of the } \\
\text { factory }\end{array}$ & $\begin{array}{c}\text { Country of } \\
\text { the investor }\end{array}$ & $\begin{array}{c}\text { Number of } \\
\text { employees in } \\
2013\end{array}$ & Production \\
\hline Logit (Radici Group) & 24 ha & Italy & 150 & Production of carpet yarn \\
\hline $\begin{array}{c}\text { Conta } \\
\text { (Candy Hoover Group) }\end{array}$ & 16 ha & Italy & 152 & $\begin{array}{c}\text { Production of fridges and } \\
\text { freezers }\end{array}$ \\
\hline $\begin{array}{c}\text { FTE automotive } \\
\text { Czechia s.r.o. }\end{array}$ & 7,5 ha & Germany & 570 & $\begin{array}{c}\text { Production of hydraulic } \\
\text { systems for brakes and } \\
\text { clutches }\end{array}$ \\
\hline $\begin{array}{c}\text { Rover Czech s.r.o } \\
\text { (Rover Plastic) }\end{array}$ & 2 ha & Italy & 8 & Production of plastic moldings \\
\hline
\end{tabular}

Source: own processing, data FTE automotive Czechia s.r.o., Conta, s.r.o. a Logit, s.r.o, Rover Czech, s.r.o.

The first corporation is the Logit, Ltd. - FDI of the Italian concern Radici Group. The second one is again a subsidiary of the Italian investor - called Hoower Candy Group. The third firm is a subsidiary of the contractor Candy Hoover Group - Rover Czech, s.r.o. The last is the current largest regional employer - FTE automotive Czechia, s.r.o. It is also a company that is the most dynamically developing company in the industrial zone Alpka (see the Fig. 1).

Fig. 1: Development of the number of employees in the analyzed FDI

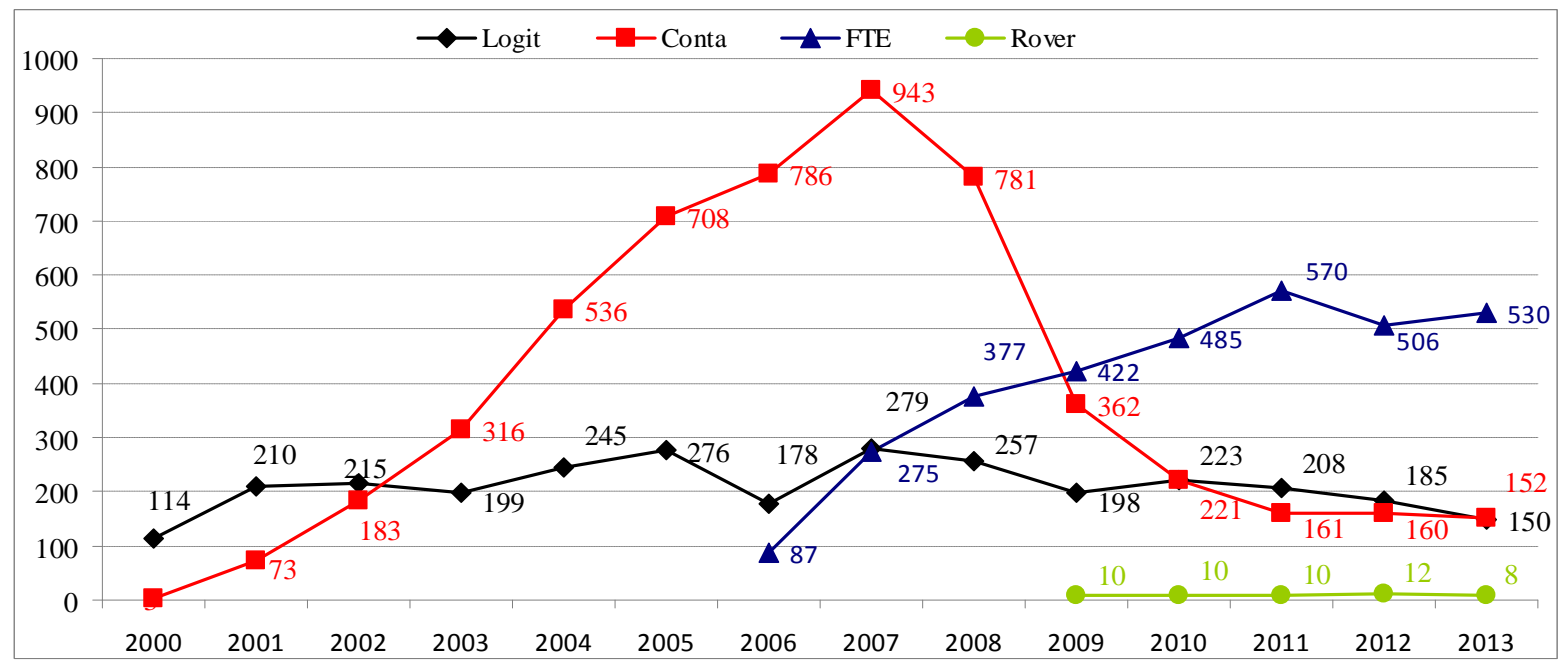

Source: own processing, data FTE automotive Czechia s.r.o., Conta, s.r.o. a Logit, s.r.o, Rover Czech, s.r.o.

The figure 1 illustrates the employee numbers development of the FDI. The figure 1 shows that Logit, s.r.o. can be described as an employer with a relatively stable number of employed people. In the years 2000 i 2013 the company employed the average of 217 employees per year. The impact of the crisis is evident in the 2009 on the employees reduction by 23\%. The continuous decline in the employment from 2010 to the present is caused by the trend of the labour productivity increase (Ministry of Justice, 2014).

The dramatic development of the employees number occurred in the factory Conta, s.r.o. In 2007 Conta, s.r.o. employed 943 employees, which made the company the largest employer in the industrial zone and strategic employer in the region. It should be noted that since 2008 the situation has inverted dramatically $i$ the company has turned from a strategic employer to the employer that is known for the annual massive dismissals within this region. The number of employees has been declining year after year. Only the part of people, who were made redundant, work in different companies in the industry zone. 
The last FDI Italian company is the Rover Czech, s.r.o. The demonstrative effect of FDI can be illustrated at these three Italian investors. A major factor of the localization for the arrival of new investors is the satisfaction of the existing ones. The Italian investor Candy Hoover Group situated their FDI in the industrial zone Alpka based on the references from another Italian investor - Radici Group, which had already based its branch Logit, s.r.o. in the industryial zone Alpka. The firm Candy Hoover Group was then followed by its contractor, the company Rover Plastic, which situated its branch Rover Czech, s.r.o. to the industrial zone,and where about 10 employees have been producing plastic moldings for the factory Conta, s.r.o. since 2009 (Kotíková, 2014).

The figure 1 also shows that only the company FTE automotive Czechia s.r.o has not been affected by the economic crisis in terms of the employees number reduction. The company now virtually profits from dismissals of workers from other factories in the IZ Alpka. Undoubtedly FTE automotive Czechia s.r.o. is the only factory in the IZ Alpka which did not make any employees redundant but even took on new employees during the economic crisis. Nevertheless it we could not be neglest the fact, that at that time the company had tied hands. The investor was attracted to PodboŚngy through varied investment incentives. The branch was established October 4, 2005, in operation got a year later - at the same year the company got investment incentives for creating new job vacancies. There was a particular precondition of creating 417 new job vacancies to April 18, 2009 (MPSV, 2009).

If the firm FTE automotive Czechia, s.r.o. had not obtained this investment incentive, it would be highly likely that the company would have made people redundant as well as other companies in the IZ. In that case the granting of this investment incentive to the enterprise FTE automotive Czechia s.r.o. worked such as a safety measure against the increase of high unemployment rate, which in 2009 stood at $11.7 \%$ in the district. The conclusion from the obtained show that if the company had not received this investment incentive to support creation of job vacancies, the increase of the unemployment rate in 2008 would had been rather higher than what it actually occurred.

The Tab. 2 is dedicated to the hypothetical rate of unemployment. In this table the selected data about the regional labour market from 2000 to 2013 are shown. It is the period when FDI began to employ workers in the IZ Alpka.

Tab. 2: The calculation of the hypothetical unemployment rate in the case of the absence of analysed FDI

\begin{tabular}{|c|c|c|c|c|c|c|}
\hline Year & & & & + & & - \\
\hline 2000 & 17,09 & 7523 & 117 & 7640 & 17,356 & 0,266 \\
\hline 2001 & 17,24 & 7521 & 283 & 7804 & 17,889 & 0,649 \\
\hline 2002 & 18,58 & 8050 & 398 & 8448 & 19,499 & 0,919 \\
\hline 2003 & 18,89 & 8091 & 515 & 8606 & 20,092 & 1,202 \\
\hline 2004 & 15,08 & 7681 & 781 & 8462 & 16,613 & 1,533 \\
\hline 2005 & 13,17 & 7457 & 984 & 8441 & 14,908 & 1,738 \\
\hline 2006 & 12,11 & 6571 & 1051 & 7622 & 14,047 & 1,937 \\
\hline 2007 & 8,93 & 4860 & 1497 & 6357 & 11,681 & 2,751 \\
\hline 2008 & 8,84 & 4624 & 1415 & 6039 & 11,545 & 2,705 \\
\hline 2009 & 11,7 & 6147 & 992 & 7139 & 13,588 & 1,888 \\
\hline 2010 & 12,36 & 6495 & 939 & 7434 & 14,147 & 1,787 \\
\hline 2011 & 12,33 & 6044 & 949 & 6993 & 14,266 & 1,936 \\
\hline 2012 & 13,29 & 6004 & 863 & 6867 & 15,200 & 1,910 \\
\hline 2013 & 10,7 & 4833 & 840 & 5673 & 12,560 & 1,860 \\
\hline Avarage & 13,59 & 6564 & 830 & 7395 & 15,242 & 1,7 \\
\hline
\end{tabular}

Source: own calculations based on date of the CSO and the data of the analysed companies 
The Tab. 2 also brings also the information on the so called hypothetical number of unemployed (U + E). In the point of the absence of analysed FDI or at their location to another region, the number of unemployed people would be increased by the number of employees in these FDI (E). Calculations in the column of the hypothetical number of unemployed thus form the sum of the unemployed and the number of employees of the analysed FDI $(U+E)$.

Based on the calculation of the hypothetical number of unemployed $(U+Z)$ is then the hypothetical unemployment rate calculated. The real unemployment rate $(u)$ and hypothetical unemployment rate , or more precisely, unemployment rate that would occur without the localization of these FDI to the IZ Alpka, is illustrated the Figure 3.

Fig. 3. Comparison of actual unemployment rate and the hypothetical unemployment rate

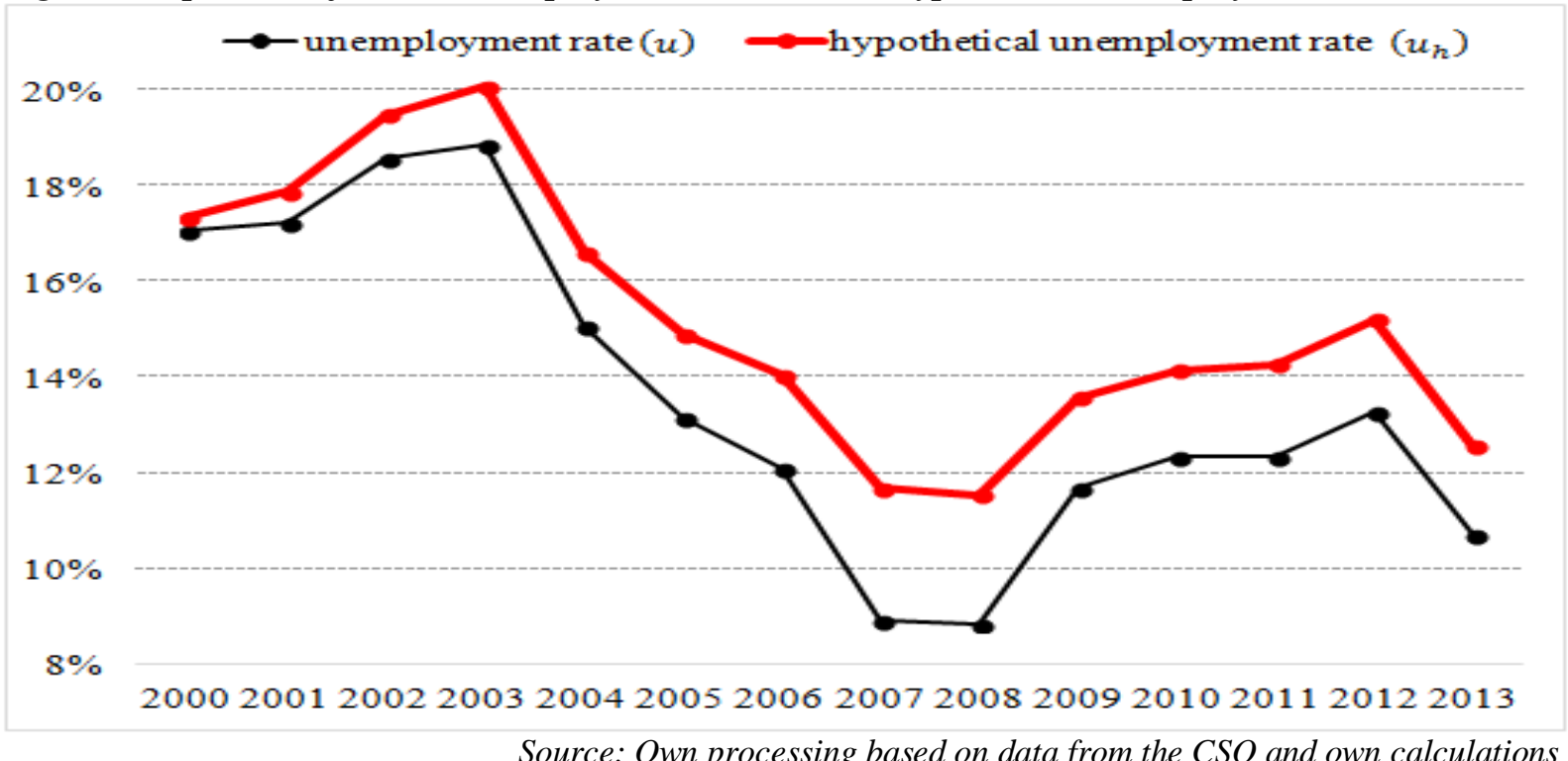

The impact of FDI on the regional labour market can be clearly seen frm the Figure 3. The concrete quantification of this effect for single years is shown in the Tab. 2 Looking at these numbers, it can be sais that the FDI from IZ Alpka can reduce the unemployment rate by an average of 1.7 percent points per year which can be regarded as a huge contribution regarding the fact that this reduction is caused by only four firms located in one relatively small IZ. From the figure it is also seen that the development of IZ Alpka follows the development of unemployment in the district Louny, but its effect on reducing the unemployment rate is rather stable, even an increasing tendency can be observed.

\section{Conclusion}

Disregarding the above mentioned demonstrative effect of Italian investors, one of the main reasons for the placement of these FDI into this region have been numerous investment incentives particularly support for the creation of new job vacancies that have been related to this region and to the IZ Alpka. Considering the above quantified contribution of these FDI to solving of the largest regional problem, or more precisely For the solution of high unemployment rate, it can be claimed that granting of investment incentives to these analysed investments can be regarded as correct and effective, because if the region was not connected with high investment incentives, there could be only speculations about location of investments to this region. Investment incentives have been proven to be the right motivation for investors, which have created hundreds of new job vacancies altogether.

FDI which is located in the IZ Alpka can be possibly described as stable, unlike the second IZ, which is located in the district Louny. Last time the company Panasonic ended up its production in the IZ Triangle and made circa 600 employees redundant. That is about $45 \%$ of workers from the IZ. Tax 
breaks expired after the period of economic crisis for companies Logit, s.r.o. and Conta, s.r.o., the situation stabilized again and there is no indication of a tendency for leaving the IZ or to make people redundant. FTE automotive Czechia s.r.o. has been developing dynamically and is currently considered as the most perspective regional employer. Considering the smallest FDI firms, the Rover Czech, s.r.o., it is not expected to end its production and leave the region. This company draws incentives and as a Conta, s.r.o. supplier is dependent on its production and as it has already been mentioned about Conta, s.r.o., it is also not expected to end up its production and change the locality of its business despite the termination of the tax break.

From the results mentioned above it can be claimed that the situation would be significantly worse on the regional labour market without these FDI, on average by 1,7 percentage points. Any business connection would not exist with local businesses, the landscape character or the town and adjacent areas form would not change. People would have no reason to move into the region without the existence of such job placement. It might be said that analysed FDI have undoubtedly a positive impact on the adjacent region. However, particular impacts and benefits are not fully quantifiable. Changing the landscape, improving social life through sponsoring coming from these companies, or the attractiveness of the region are difficult to quantify.

\section{Literature}

[1] CzechInvest, (2013). Investment Incentives. Database of CzechInvest, [online]. [cit. 2013-3-28]. Available at: 〈http://www.czechinvest.org/investicni-pobidky-nove>.

[2] CSO. Statistical Yearbook of the Usti Region 2012 [online]. Ústí nad Labem: Czech Statistical Office, [cit. 20.03.2014]. ISBN 978-80-250-2261-0. Available at: <http://www.czso.cz/csu/2012edicniplan.nsf/t/D0003FD8F8/\$File/42.

[3] KOCOUREK, A. a ĠMANOVÁ, J., (2013) Regionální benchmark stability pŚmých zahrani! ních investic

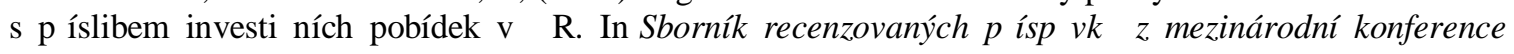
Hradecké ekonomické dny 2013, díl II. Hradec Králové: Univerzita Hradec Králové. pp. 276 ï 287. ISBN 978-80-7435-250-8.

[4] Ministry of Justice of the Czech Republic, (2013). Business register: collection of documents [online] [cit. 2011-08-10]. Available at: 〈http://www.justice.cz〉.

[5] MoLSA, (2013). Time series. [online]. [cit. 28.03.2013]. Available at: $<$ http://portal.mpsv.cz/sz/stat/nz/casove_rady>.

[6] PAVLÍNEK, P., (2004). Regional Development Implications of Foreign Direct Investment in Central Europe. European Urban and Regional Studies, vol. 11, iss. 1, pp. 47-70. ISSN 0969-7764. DOI 10.1177/0969776404039142.

[7] GMMANOVÁ, J., (2013) Evaluation of the Impact of Investment Incentives on Real Economic Convergence between the Regions of the Czech Republic. In Economic Policy in the European Union Member Countries. Ostrava: Vysoká ǵkola báRská ï Technická univerzita v Ostravク pp. 304 ï 312. ISBN 978-80-248-3095-7. 